\title{
Poverty and the Economic Transition in the Russian Federation*
}

Thomas A. Mroz and Barry M. Popkin

University of North Carolina

\section{Introduction}

In what some describe as one of the great natural experiments of our time, the Russian Federation has introduced a series of sweeping economic reforms over a very short period of time, beginning in January 1992. These include the elimination of most food subsidies; the reduction of other food subsidies and subsidies for fuel and most other basic commodities; the use of freely fluctuating market prices; the privatization of selected state enterprises; the creation of conditions for the establishment of a private sector in many areas of economic activity; and the initiation of a process that will ultimately transfer much property and land into private ownership. The result is rapid economic and social change. Western observers agree that this transformation will produce significant dislocations and affect many people adversely. Most expect that the worst dislocations will be in the short term, with the transformation leading to substantial long-term benefits. The Russians involved in the design and implementation of this transition, as well as Russian politicians, have been and continue to be deeply concerned about the impacts of the reforms on poverty levels.

The concept of poverty received little attention in the former Soviet Union. In many ways, there had never been an official recognition of poverty in Russia or the other former Soviet Union republics. The Soviet social science research literature focused instead on the concept of a socially acceptable standard of living. This standard was based on an ideal diet and set of living conditions that it was hoped all members of the former Soviet Union would attain. Those earning incomes below this norm were considered to be in maloobespechennost ("underprovision," a term referring to those who live poorly and are lacking in supplies) and thus, in some respects, to be living in poverty. Their definition of poverty was based partly on political and other

(c) 1995 by The University of Chicago. All rights reserved.

0013-0079/96/4401-0001\$01.00 
concerns, but it did little to identify the truly poor population. Nearly all earlier work in the former Soviet Union on poverty related to this concept, and what was termed a poverty line encompassed much of the population. Such arbitrary definitions of poverty were inadequate for identifying the truly poor in Russia before the breakup of the Soviet Union. These definitions are certainly of little use to policymakers trying to ease the burdens of the transition to a market-based economy on the poorest members of the society. The new concept of poverty (bednost) has only emerged during the past few years.

This article uses more conventional, need-based measures of poverty lines to present profiles of poverty in Russia during the period immediately following the economic transformation that began in early 1992. It presents descriptions of the poor in Russia, obtained from a survey designed specifically to monitor the impact of the social reform on the Russian populace. Since the current social protection system in Russia is predominantly based on the historical pattern of low income per capita, we begin this article with a brief examination of historical data and the statistical system used by the Soviet government.

We analyze the incidence of poverty with data collected by the Soviet Consumer Budget Survey during 1989 and compare these measures to data obtained from a representative sample of the city of Taganrog in the same year. Even though this is a comparison of a national, but nonrepresentative, sample for all of Russia to a representative sample of just one city, the large differences between samples in poverty estimates suggest that the old Soviet surveys did not provide an adequate description of the needy in Russia. There is almost no national information available for the time before 1992 other than the Consumer Budget Surveys. At best the Soviet data can provide rough baseline measures of poverty in Russia before 1992 .

The article then draws on data from the Russian Longitudinal Monitoring Survey (RLMS) collected during the summers of 1992 and 1993. In conjunction with a more realistic definition of the poverty line, these data provide more recent and comprehensive information on the patterns of poverty in Russia. These patterns differ dramatically from those implied by the Consumer Budget Surveys, but they are in general accord with those obtained from the Taganrog survey. The RLMS data do indicate some widespread poverty among particular segments of Russian society, with the incidence of poverty falling mostly on parts of the population that were severely underrepresented in the Consumer Budget Surveys.

\section{Poverty Norms}

The lack of consideration of poverty in the former Soviet Union was due to a combination of circumstances. First, at least during the 1970s and 1980s, there was little absolute poverty in the Russian Federation 
in terms of inadequate diet or hunger. State enterprises served as the main instrument for providing social protection. Their guarantee of employment and a wide range of benefits and subsidized goods and services led to minimal poverty, or at least that was the general impression.

Second, questions of income distribution and inequality were traditionally explained more in political than in economic terms. In addition, data collection and the compilation of official statistics were heavily influenced by planning considerations. Until the late 1960s, official admission or even discussion of income distribution and any problems associated with unequal income were not permitted. ${ }^{1}$ The euphemistic maloobespechennost did not even come into use until the late 1960s. The 1971-75 plan discussed this concept, but the term bednost (poverty) was never used. It is not surprising that the existing statistical system did not provide a basis for actually measuring those who were poor.

The Russian republic and all republics formerly part of the USSR traditionally used an absolute income level cutoff to identify the poor. This income level, called the social minimum income, focused on food consumption and living standard norms rather than on a basic minimum or subsistence level below which people should not fall. The Soviet Labor Research Institute developed the social minimum income norms in 1965 by establishing standards for all aspects of consumption, from food and clothing to housing, holidays, and so forth. ${ }^{2}$ The market basket associated with this social minimum income provided over 3,000 calories per person per day, and the proportion of animal and dairy products in this diet was very high. ${ }^{3}$ The State Statistical Office (Goskomstat) of the Soviet Union updated the social minimum income level by using republic-wide average prices to cost out the market basket. The Goskomstat used price data they collected that were based on state store reporting on prices charged for food. Because of food shortages and a wide range of practices followed by consumers and state stores, it is unlikely these prices were the ones consumers faced. The absolute income level chosen designated large portions of the population as poor. ${ }^{4}$

After the USSR dissolved, the Russian government revised this social minimum income and developed a poverty line that is much closer to a true poverty line. ${ }^{5}$ This poverty line is used by both the central government and all oblasts (the Russian equivalent of U.S. state governments) to establish pension, minimum wage, and welfare payment levels. There was, and continues to be, great concern that no one would be hungry or poor, so this new line was set 5\%-10\% higher than would have been the case if Western dietary guidelines had been adopted. This new poverty line should be adequate for describing the incidence of poverty, and we use it in the analysis pre- 
sented below. This market basket approach is comparable to the Thrifty Food Plan of the U.S. Department of Agriculture, which is the basis of the U.S. (Orshansky) poverty line. ${ }^{6}$

The new Russian Federation poverty line contains adjustments for the age and gender composition of the household. It incorporates separate nutritional standards for six demographic groups: (1) children younger than 6 years old; (2) children age 6-17; (3) men age 18-59; (4) women age 18-54; (5) men age 60 and older; and (6) women age 55 and older. The approach created low-cost food baskets for each demographic group, both to meet their nutritional standards and to reflect typical consumption patterns. After pricing each market food basket at national average prices, age- and gender-specific multipliers yield individual poverty lines for each demographic type. The sum of the individual poverty lines in a household defines the household poverty line. The poverty lines are recalculated each month to reflect the changing absolute and relative price levels of the food baskets. Since the composition of each food basket remains constant across time, these poverty lines do not reflect individuals' abilities to economize when relative prices change. In summary, the household poverty lines reflect the age and gender composition of the household and temporal variations in prices, but they do not incorporate additional adjustments for economies of scale or adjustments for regional variations in prices or market baskets.

\section{Data}

In this analysis we use three data sources to describe the incidence of poverty in Russia. For 1989 we use the Consumer Budget Survey and a set of surveys conducted in the city of Taganrog. While neither of these surveys is representative of the Russian population, they do provide the best information available on household composition and incomes during the late 1980 s. A serious drawback for this analysis is the lack of machine-readable household-level data sets for these two data sets. We must rely on previously compiled tabulations, so the across-data set comparisons cannot be as incisive as we had hoped. For 1992 and 1993, we use the Russian Longitudinal Monitoring Survey (RLMS). This is a panel data set, and data collection started during the summer of 1992. Its primary purpose is to measure the impact of the reforms on a representative sample of the Russian population, making it an ideal data set for this study.

\section{The Consumer Budget Survey}

The State Committee on Statistics (Goskomstat) collected its own series of income and consumption data on an annual basis. The sample is based on lists of public enterprises from the 1950s that have been updated in a nonsystematic manner. This list of companies and enter- 
prises was not selected randomly, and it is not representative of Russian enterprises. Within the enterprises, individuals with full-time contracts who were willing to be interviewed provided very detailed income, food consumption, and expenditures data on a weekly basis collected over a year. In 1989, about 49,000 Russian households were surveyed. A small sample of pensioners was also included. Income data were collected continuously but represent only market earnings; they significantly underrepresent home production and other nontraditional sources. The Goskomstat survey instrument is nearly a direct translation of the 1950s U.S. Bureau of Labor Statistics income and expenditure survey.

\section{Taganrog Surveys}

For over 20 years, the Institute for Socio-Economic Population Studies has conducted surveys in Taganrog, a city with a population of 400,000 located in the central region of the Russian Federation. ${ }^{7}$ A major goal of the Taganrog survey was for it to be generally representative of cities in the Russian Federation. Detailed comparisons of Taganrog with other cities with 1970 census data revealed no peculiar features of Taganrog. ${ }^{8}$ Taganrog is a city with a varied industrial base. It was selected by a group of eminent Russian economists and sociologists as the city to study after their analysis showed it matched many of the sociodemographic characteristics of urban Russia. A great deal of additional analysis was undertaken to show that the Taganrog population matched the profile of the average Russian city. Similar studies in 1969-71 for Tallin and Kostroma found comparable results.

Two separate sets of panel studies were conducted in Taganrog. We utilize results from the one that focused on economic issues. The most recent available information is from a survey of 4,000 households in 1989. The households were selected with a sample frame that attempted to be representative of the city's population. The survey contains detailed income and consumption measures.

\section{Russian Longitudinal Monitoring Survey (RLMS)}

The RLMS is a household-based survey designed to monitor systematically the effects of the Russian reforms on the economic well-being of households and individuals. The first nationally representative sample of the Russian Federation was developed specifically for this survey. This survey, which we organized, is a collaborative effort of the State Statistical Office, the University of North Carolina at Chapel Hill, and the Russian Center of Preventive Medicine, with the assistance of the Russian Institute of Sociology. The survey is designed as a longitudinal survey of households.

In this article we present summary measures from the first and third rounds, collected during August-October 1992 and May-July 1993. 
Since this is a new data source, we give a brief description of the sampling frame and survey instruments. These data will become available for public use during 1995-96 from the Inter-University Consortium for Political and Social Research (ICPSR).

Sampling design of the RLMS. The survey covers the eight regions of the Russian republic. These regions vary substantially in geography, economic development, public resources, and health indicators. The initial sample of households for the RLMS was identified from a stratified three-stage cluster sample of residential addresses. Cities, as well as both urban and rural portions of rayons (political and geographic units about the size of U.S. counties), were the area units selected in the first stage. Probability Proportionate to Size (PPS) simple sampling was used to select the rayons. The rayons were stratified by the eight regions and the percent urban population within each rayon. Within each of the areas chosen in the first stage, a sample of 10 voting districts was randomly chosen, again by PPS systematic selection, from a geographically ordered list of the voting districts falling in that area. ${ }^{9}$ Finally, within each selected voting district a simple systematic sample of voters was chosen. The indicated address for each selected voter was visited, and the household in residence at that address was selected to be part of the sample. In the event that more than one household lived at a sample address, only one household was chosen randomly for participation. Overall, 7,200 households were targeted for interview in the first round of this survey. The final sample providing data for round 1 contained 6,485 households and 17,179 individuals. This is an initial response rate of $90.1 \%$. In round 3, 6,163 households provided data on 15,783 individuals. By round 3, 728 households were lost to follow-up, and 363 new households responded to the round 3 questionnaire that had not provided data in the round 1 interview. Of these 363, 299 had been added in round 2 and 64 were new in round 3.

Instruments. Two separate questionnaires provide the information from the RLMS used in this analysis. A household questionnaire collected detailed sociodemographic and economic data. Individual questionnaires administered to each person in each household provide information on time use, economic activities, demographic characteristics, dietary intakes, and anthropometric and other health measures. An attempt has been made to measure all state, free market, and home production sources of income.

\section{Estimates of Poverty in Russia}

Poverty Prior to 1992

We set the baseline for this analysis of the incidence of poverty by focusing on data from 1989, about 3 years before the major transition in prices and employment began. B. M. Popkin, in conjunction with 
several Russian experts, established 150 rubles per capita per month as the new poverty line for $1991 .^{10}$ In distributional terms, the population with an income under 100 rubles per capita per month in 1989 matches those in the group under 150 rubles in 1991, and we use this 100-rubles cutoff to set the poverty line for 1989 . This poverty line more closely reflects a subsistence income measure than the minimal social income measure previously used by the Russian Federation. For example, the proportion of the population estimated to be poor in 1991 dropped from $85 \%-88 \%$ under the subsistence minimum income to $13 \%$ with this new poverty line. ${ }^{11}$

The first column of table 1 presents the population distribution in Russia by household per capita income groups from the Consumer Budget Surveys. The second column presents the household distribution of income from the Taganrog survey. The income figures are in current income terms. During 1989, the Consumer Budget Survey indicates that $16 \%$ of all people in the Russian republic had per capita monthly incomes below 100 rubles. ${ }^{12}$ The Taganrog survey shows that $30.8 \%$ of families are living below the poverty line. ${ }^{13}$ This comparison of individual and family incidences of poverty most likely understates the true differences across the two surveys, as the individual incidence of poverty is almost always skewed toward those in larger families.

TABLE 1

Distribution of Russian Federation Population by Average Income Level, 1989, Consumer Budget Survey AND TAGANROG SURVEY

\begin{tabular}{lcc}
\hline & $\begin{array}{c}\text { Consumer Budget } \\
\text { Survey (\% of } \\
\text { Individuals in the } \\
\text { Per Capita } \\
\text { Average Monthly } \\
\text { Income (Rubles) }\end{array}$ & $\begin{array}{c}\text { Taganrog Survey } \\
\text { (\% of Households } \\
\text { in the Per Capita } \\
\text { Income Category) }\end{array}$ \\
\hline Up to 50 & .5 & 3.0 \\
$50-75$ & 4.5 & 9.9 \\
$75-100$ & 11.0 & 17.9 \\
$100-125$ & 15.4 & 20.2 \\
$125-150$ & 15.7 & 17.2 \\
$150-175$ & 14.0 & 11.6 \\
$175-200$ & 11.1 & 6.9 \\
$200-250$ & 14.4 & 8.4 \\
$250-300$ & 7.4 & 1.3 \\
Over 300 & 6.0 & 100.0 \\
\hline
\end{tabular}

Source.-Consumer Budget Survey, Russian State Statistical Bureau (Goskomstat).

Note.-Sums may not total to 100.0 because of rounding. 
While Taganrog is only one medium-sized city, these data do help to gauge some of the inadequacies arising from the sample frame of the Consumer Budget Surveys. In particular, there is a strong presumption that the Goskomstat sample frame is likely to underrepresent the poor. This simple comparison suggests that a reliance on the Consumer Budget Survey may yield a significant undercount of those in poverty before the economic reforms in 1992.

These two data sets do, however, yield a few insights into the incidence of poverty in the Russian population before the economic reforms. In both surveys, salaries are the dominant source of family income for those below the poverty line in 1989, suggesting that much of the incidence of poverty falls on working persons. Both surveys also indicate that families with children, especially large families and those headed by single parents, make up a significant fraction of the poor. Additional tabulations from the 1991 Consumer Budget Survey reveal that nearly $20 \%$ of all children live in families below the poverty line and that nearly $30 \%$ of individuals in families with three or more children fall below the poverty line. The true fractions of young children and persons from large families in poverty are most likely much higher. The 1989 Taganrog survey indicates that families with only pensioners and their dependents encompass fewer than $30 \%$ of the families in poverty, while households with at least one member temporarily not working make up over $17 \%$ of all families in poverty. These aggregate data lead us to question the often-made assertion in the former Soviet Union that the poor and the pensioners are synonymous.

From the Goskomstat and Taganrog information, the emerging picture of poverty before the transition is one composed disproportionately of children-particularly from larger families. As indicated in the Taganrog survey, those temporarily unemployed also make up a sizable fraction of the poor. This strongly suggests that the likelihood of additional poverty associated with either short-term or longer-term economic dislocation may be significant if workers become unemployed as the economic reforms progress. Female-headed households and pensioner households make up the bulk of the rest of the poor, but it is not expected that these groups will grow significantly due to the imposition of the economic reforms. The Taganrog survey, however, suggests a higher overall incidence of poverty than does the Consumer Budget Survey.

Poverty during the Transition to a Market-Based Economy

During the period preceding and following the January 1992 liberalization of prices, many scholars believed that poverty in Russia was becoming rampant. Many suspected that there was serious hunger and malnutrition, even in Moscow. ${ }^{14}$ Public opinion polls echoed the same fears and concerns. ${ }^{15}$ Many Russian and Western scholars perceived 
pensioners to constitute the largest group of poor households. ${ }^{16}$ Due to the demographic structure in Russia, the pensioners group was clearly large and rapidly increasing in size. ${ }^{17}$ The more than 33 million pensioners in the Russian Federation reflected, in part, a retirement age that is low in relation to European and other Western countries (age 55 for women, 60 for men). Other groups suspected of being susceptible to poverty were families with large numbers of children, families headed by women, and families with handicapped wage earners. ${ }^{18}$

The data reviewed here suggest that this perception regarding the pattern of poverty in the Russian Federation has been incorrect. In particular, the analysis of the RLMS data indicates that the pensioners are not uniformly poor. Nor does this group constitute a majority of the poor in Russia; in 1992 about $15 \%$ of poor persons were of retirement age, and this figure drops to less than $10 \%$ in 1993 . These misperceptions have led to the exclusion of a large class of low-income persons from government social protection programs. In addition, a significant segment of those currently considered to be poor actually are not poor. Where families are small, as in much of European Russia, pensioners do represent an important, but not dominant, group of the poor. In other areas where fertility rates are higher (e.g., several Moslem oblasts), there is significantly more poverty among families with an above-average number of children. ${ }^{19}$

We use the first round of the RLMS for the analysis of the poor during 1992, the first year of the transition period. What is shown is that many of the groups expected to be most vulnerable to the reform process-namely, those without jobs, the young, and women-are indeed heavily represented among the poor. Moreover, we also uncover significant gaps in the official transfer systems designed to provide a social safety net.

The income measure used for uncovering the incidence of poverty attempts to capture each household's disposable income during the period preceding the time of the interview. It includes labor incomes, net earnings from individual and household economic activities, pensions, other government and individual transfers to the household, and withdrawals from savings. ${ }^{20}$ The income measure also contains imputed ruble values for in-kind payments and transfers, as well as the value of agricultural goods produced on individual land plots. In the concluding section of the article we examine briefly the importance of government transfers and pensions for keeping households out of poverty.

Table 2 presents the composition of poverty in Russia from July to October 1992 calculated from the first round of the RLMS. This table focuses on households and uses total household income as a proportion of the household's poverty line to categorize incomes. The 


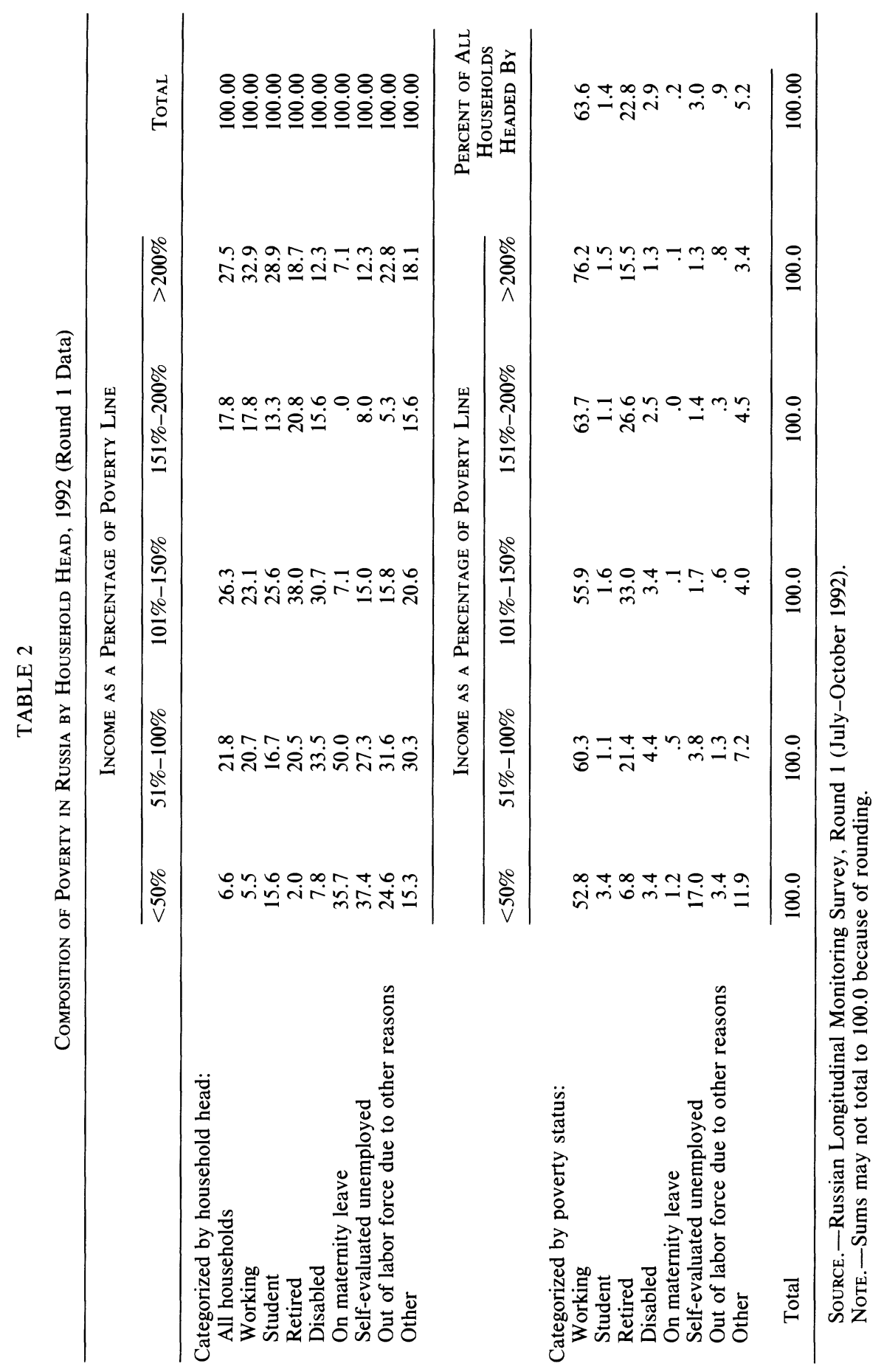


top part of the table defines the distribution of income for various household types defined by the status of the household head. ${ }^{21}$ As an example, of those households headed by a retired person, $2.0 \%$ have household incomes less than one-half the poverty line, a total of $22.5 \%$ have incomes below the poverty line, and $77.5 \%$ of households headed by the elderly have incomes above the poverty line. The bottom part of this table describes the composition of the households within income categories. Of the households in the lowest income bracket, $52.8 \%$ are headed by a working person.

Overall, $28.4 \%$ of all households fell below the poverty line in mid-1992, while $6.6 \%$ of all households received income less than onehalf of the poverty line. Households headed by working individuals are only slightly less likely to be poor (below the poverty line) or very poor (below one-half the poverty line) than average. Households headed by retired individuals are also slightly less likely to fall below the poverty line than an average household is, but they are much less likely to be among the very poor. Households headed by disabled persons are about $45 \%$ more likely to fall below the poverty line. Households headed by an unemployed individual are almost six times as likely to be very poor and more than twice as likely to be below the poverty line. Over $85 \%$ of households headed by a woman on maternity leave are in poverty.

The bottom part of table 2 reveals that households headed by working individuals make up about three-fifths of all families in poverty. Households headed by an unemployed individual account for $17 \%$ of the very poor and $6.9 \%$ of all households in poverty. Households headed by retired individuals account for fewer than $7 \%$ of the very poor households, and overall $18 \%$ of the households in poverty. Each of the other groups accounts for less than $5 \%$ of the number of households in poverty.

Table 3 contains identical breakdowns for July-September 1993, from the third round of the RLMS. ${ }^{22}$ During this 1-year period, the frequency of poverty status among households changed very little (28.4\% in 1992 and $28.2 \%$ in 1993). The fraction of very poor households, however, increased to $9.1 \%$. Those working in 1993 are slightly more likely to be below the poverty line than in 1992 . Somewhat surprisingly, only $8.8 \%$ of households headed by a retired person were in poverty in 1993. A comparison of the bottom parts of tables 2 and 3 reveals that the only major changes in the composition of families below poverty are the decline in the fraction of the poor households headed by retired persons (from 18\% of all households below poverty in 1992 to $7.4 \%$ in 1993) and the increase in the fraction of poor households headed by a working person (from 58.6\% in 1992 to $63.8 \%$ in 1993).

Appendix table A1 lists changes in the percent of households, 


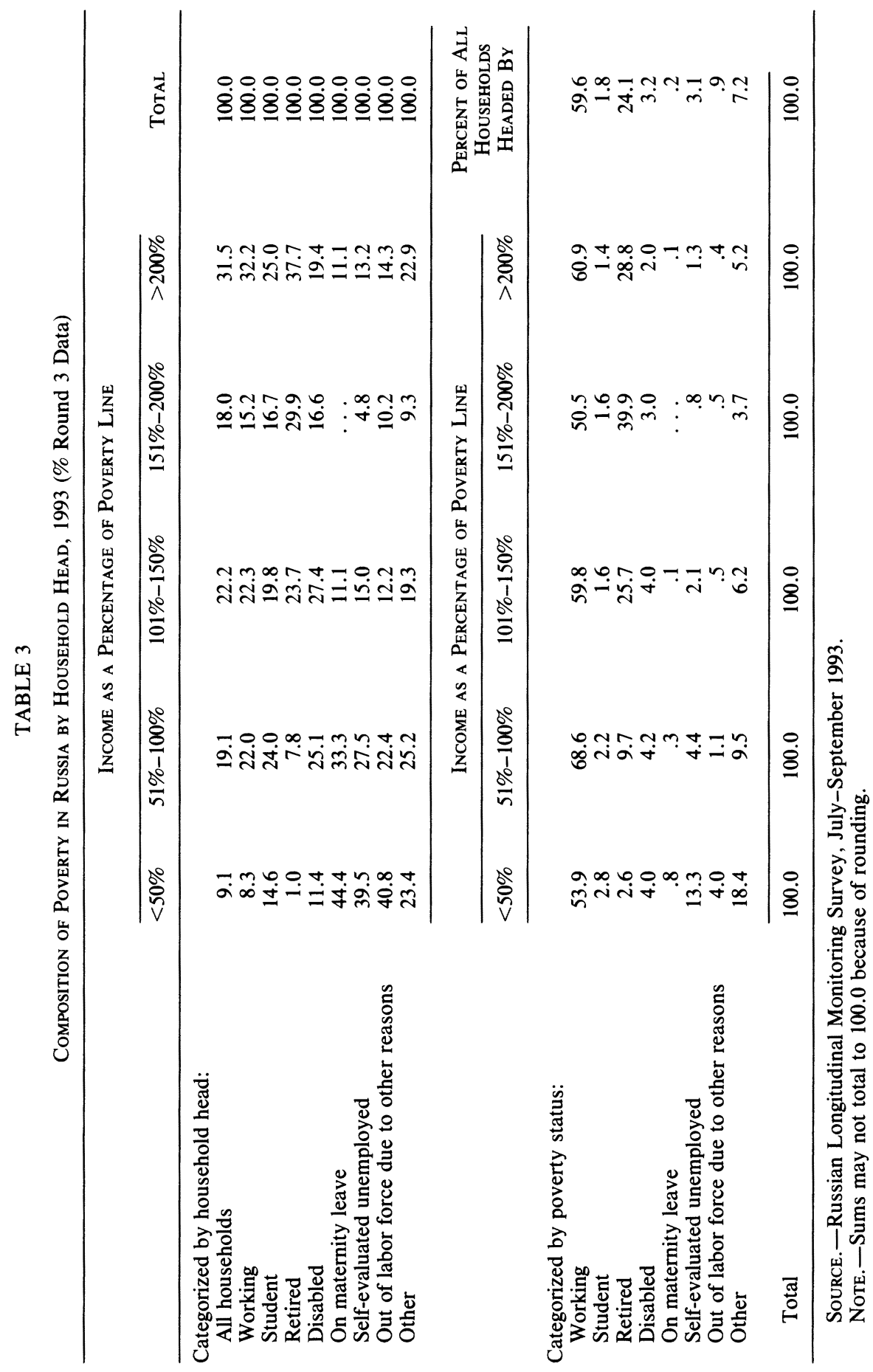


separately by household head categories, within each income group from 1992 to 1993; it also includes estimates of the standard error of these changes. ${ }^{23}$ For the most part, the only statistically significant changes are associated with those household head categories that make up a large share of the households. The increase in the percent of households headed by working individuals that are in the lowest income category is significant. Additionally, all of the changes for households headed by retired individuals are statistically significant, and Appendix table A1 reinforces the interpretation that from 1992 to 1993 households headed by retirement-age individuals experienced significant improvements in income levels.

Table 4 presents the incidence of poverty by age and gender categories in 1992 and 1993. The top numbers in each pair of rows are the percent of individuals in the specified age-gender group that falls in the corresponding household income category in 1992; the bottom numbers in each pair of rows present the same information for individuals in 1993. Overall, the fraction of individuals in poverty increased slightly (from $32.4 \%$ in 1992 to $34.8 \%$ in 1993). But there was a shift toward more individuals being in very poor households during 1993 (8.2\% in 1992 and $11.7 \%$ in 1993).

Table 4 reveals some startling changes in the incidence of poverty. In $1992,41.4 \%$ of all children lived in households below the poverty line, and this fraction increased to $47.4 \%$ in 1993 . The incidence of poverty for young, working-age adults also increased, from $31.9 \%$ in 1992 to $38.2 \%$ in 1993 . Older, working-age men and women experienced slightly smaller increases in the incidence of poverty. Retirement-age individuals fared much better over this year, with only one in six retirement-age women in poverty and one in 11 retirement-age men in poverty in 1993. Appendix table A2 shows the changes in the percent of individuals in each income category and the standard error of these changes. For all except the elderly, there are significant increases in the proportions of individuals in the lowest income category. For the elderly, there are statistically significant increases in the proportions in the two highest income categories and significant declines in the proportions of persons in poverty.

Table 5 presents detailed information on the proportion of individuals in particular poverty categories from the age and gender groups examined in table 4 , and here we summarize some of the main findings from this table. In 1992, children younger than 18 made up $27.2 \%$ of the total population but $34.8 \%$ of the poor population. By 1993, the proportion of children in the population hardly changed, but children represented nearly $37 \%$ of those in poverty. Relative to the population as a whole, in 1992 working-age adults were slightly overrepresented in the poor and they were only slightly overrepresented in 1993. In 1992, retirement-age persons constituted $21.2 \%$ of the population and 
TABLE 4

Age-Gender InCidence of Poverty, 1992 and 1993

\begin{tabular}{|c|c|c|c|c|c|c|}
\hline \multirow{2}{*}{$\begin{array}{l}\text { Age-Gender } \\
\text { Group }\end{array}$} & \multicolumn{6}{|c|}{ Household Income as a Percentage of the Poverty Line } \\
\hline & $<50 \%$ & $51 \%-100 \%$ & $101 \%-150 \%$ & $151 \%-200 \%$ & $>200 \%$ & Total \\
\hline \multicolumn{7}{|l|}{$\begin{array}{l}\text { Less than } 6 \\
\text { years old: }\end{array}$} \\
\hline 1992 & 12.7 & 28.7 & 22.1 & 15.7 & 20.8 & 100.0 \\
\hline 1993 & 15.8 & 30.9 & 22.4 & 12.2 & 18.7 & 100.0 \\
\hline \multicolumn{7}{|l|}{$7-17$ years } \\
\hline 1992 & 11.7 & 29.8 & 24.4 & 15.6 & 18.6 & 100.0 \\
\hline 1993 & 18.3 & 29.3 & 23.4 & 11.3 & 17.6 & 100.0 \\
\hline \multicolumn{7}{|l|}{$\begin{array}{l}18-30 \text { years } \\
\text { old: }\end{array}$} \\
\hline 1992 & 9.6 & 22.4 & 22.5 & 16.9 & 28.7 & 100.0 \\
\hline 1993 & 12.7 & 25.6 & 22.4 & 14.0 & 25.3 & 100.0 \\
\hline \multicolumn{7}{|l|}{$\begin{array}{l}\text { Women } 31-54 \\
\text { years old: }\end{array}$} \\
\hline 1992 & 8.1 & 23.6 & 24.3 & 17.0 & 27.0 & 100.0 \\
\hline 1993 & 12.5 & 23.7 & 22.5 & 14.7 & 26.7 & 100.0 \\
\hline \multicolumn{7}{|l|}{$\begin{array}{l}\text { Men } 31-59 \\
\text { years old: }\end{array}$} \\
\hline 1992 & 7.3 & 23.8 & 24.4 & 17.1 & 27.5 & 100.0 \\
\hline 1993 & 11.9 & 24.7 & 23.7 & 14.5 & 25.2 & 100.0 \\
\hline \multicolumn{7}{|l|}{$\begin{array}{l}\text { Women } 55+ \\
\text { years old: }\end{array}$} \\
\hline 1992 & 3.6 & 21.3 & 31.3 & 19.2 & 24.5 & 100.0 \\
\hline 1993 & 3.7 & 13.0 & 23.8 & 22.9 & 36.6 & 100.0 \\
\hline \multicolumn{7}{|l|}{$\begin{array}{l}\text { Men } 60+ \\
\text { years old: }\end{array}$} \\
\hline 1992 & 1.9 & 15.0 & 33.5 & 20.7 & 28.8 & 100.0 \\
\hline 1993 & 1.1 & 8.3 & 17.1 & 25.8 & 47.7 & 100.0 \\
\hline \multicolumn{7}{|l|}{$\begin{array}{l}\text { Total pop- } \\
\text { ulation: }\end{array}$} \\
\hline 1992 & 8.2 & 24.2 & 25.5 & 17.2 & 25.0 & 100.0 \\
\hline 1993 & 11.7 & 23.2 & 22.7 & 15.7 & 26.7 & 100.0 \\
\hline
\end{tabular}

SourCE.-Russian Longitudinal Monitoring Survey, July-October 1992 and JulySeptember 1993.

NOTE.-Sums may not total to 100.0 because of rounding.

only $14.9 \%$ of the poor. By 1993 , retirement-age persons made up less than $10 \%$ of those in poverty. Tables 4 and 5 demonstrate that the impacts of the economic reforms were not borne uniformly across age categories. Retirement-age persons fared much better than younger adults, and children appear to have borne the brunt of the reforms.

To illustrate more clearly the incidence of poverty in 1993, table $6 \mathrm{~A}$ presents the distribution of particular household types in the income distribution, and we categorize household types by the presence of particular types of individuals in the household. Unlike the breakdowns used in the previous tables, the household-type categories in table $6 \mathrm{~A}$ are not necessarily mutually exclusive. The first row of this 


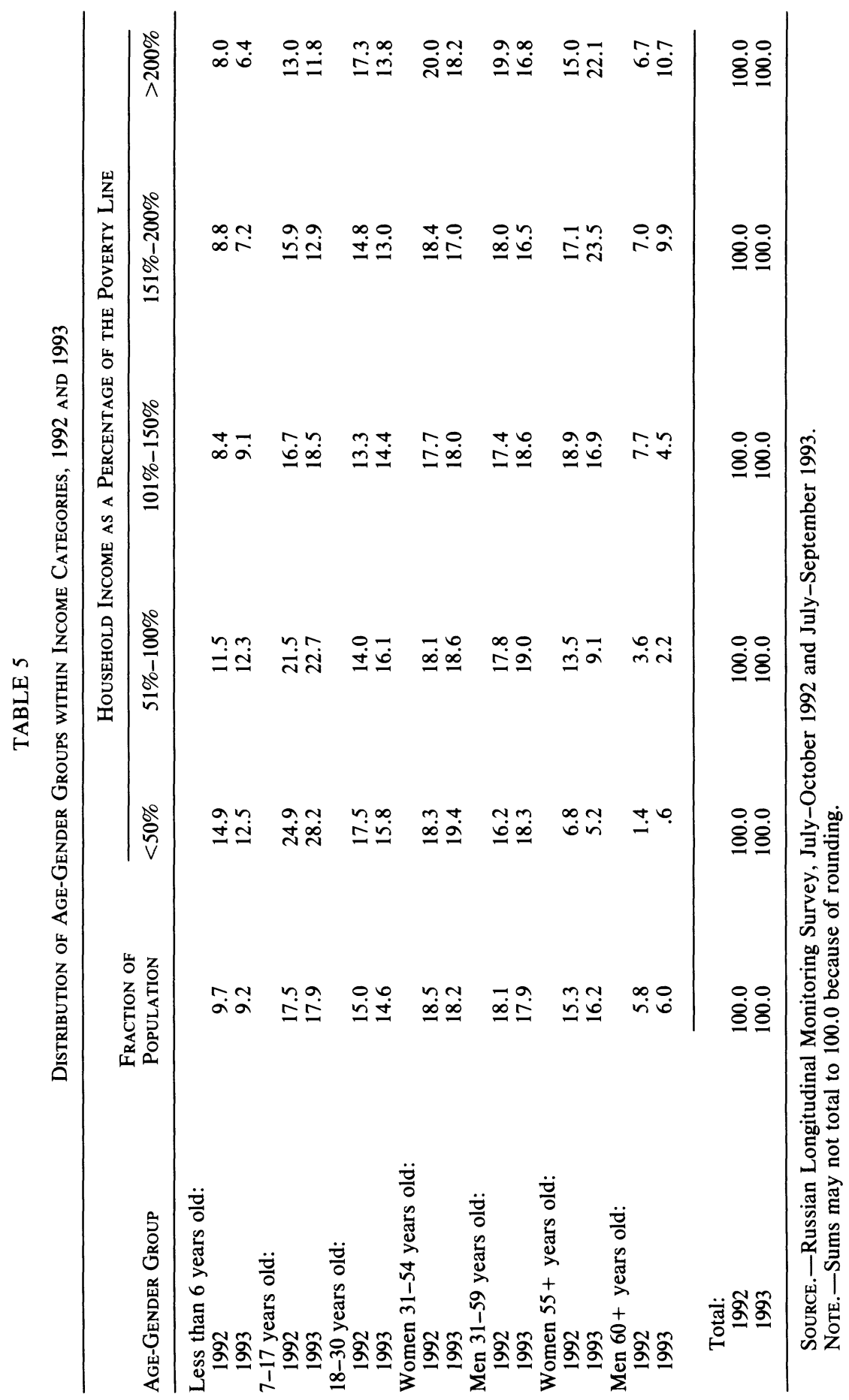




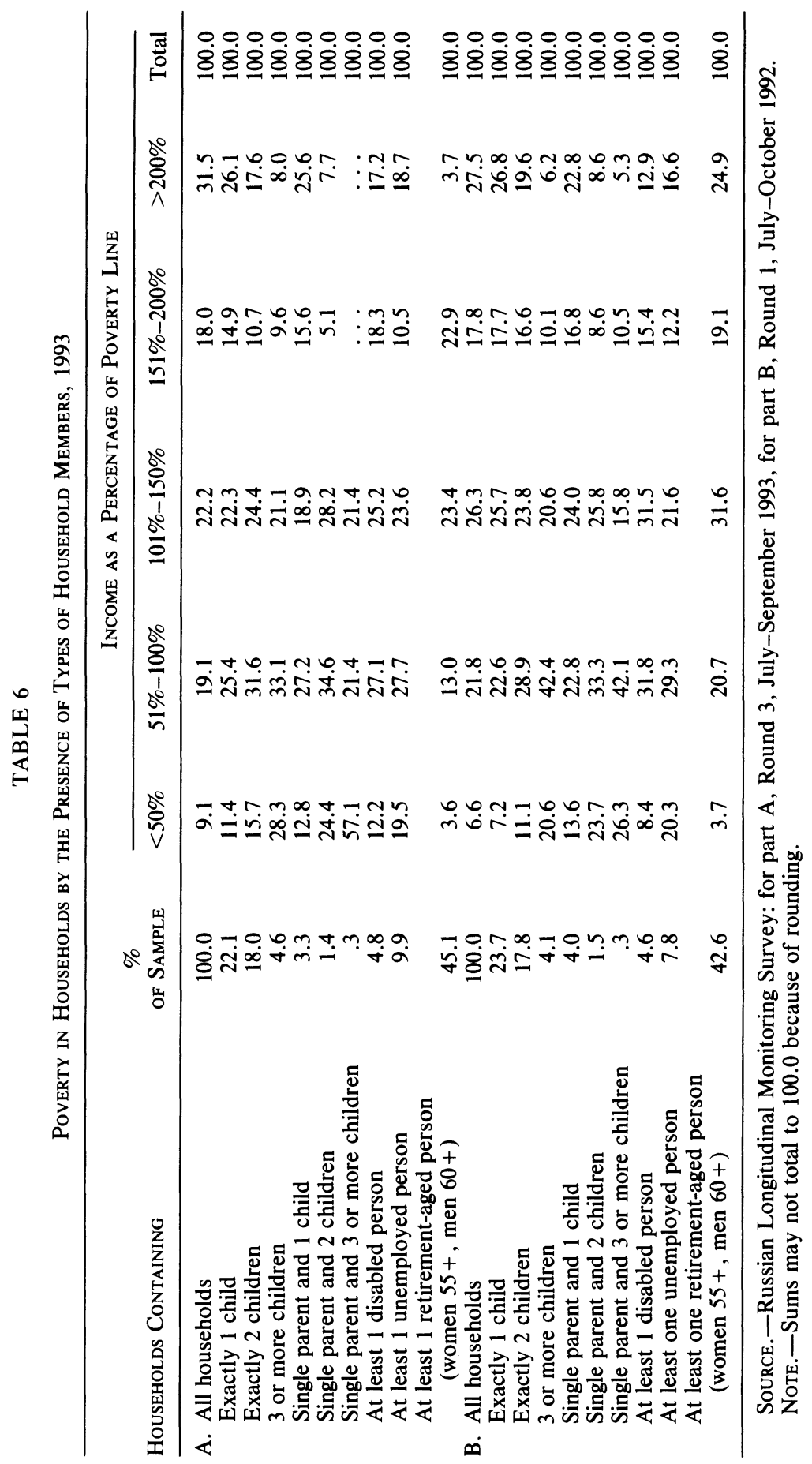


table presents the income distribution for all households. Table 6B contains similar information for 1992.

The first part of table 6A presents the income distribution characterized by the number and ages of children in the households in 1993. Households with children are much poorer than the total population, and the incidence of poverty rises quickly with the number of children in the household. Over $60 \%$ of all households with three or more children are below the poverty line, and over two-thirds of all poor households contain children. Approximately $45 \%$ of all households with at least one child younger than age 7 are shown to be below the poverty line in 1993.

The large number of families with children falling below the poverty line may, in part, be an artifact of the Russian poverty line, which does not adjust for economies of scale in household size. ${ }^{24}$ Poverty lines in the United States and in European countries, for example, do take scale effects into account. Note, however, that housing costs are the major source of these economies of scale and that housing costs make up only a minuscule fraction of Russian budgets. While adjustments to the Russian poverty line for economies of scale in household size would certainly reduce the fraction of large households classified as poor, most likely the adjustment would not be substantial.

The bottom part of table $6 \mathrm{~A}$ describes the incidence of poverty for several groups believed to be most susceptible to adverse consequences from the economic reform. One household in 20 is a single parent household with children, and the poverty rates for such households are quite high. Overall, $47.6 \%$ of single-parent households are in poverty in 1993, up from $43.4 \%$ in 1992 . Nearly two-fifths of these poor, single-parent households had incomes less than one-half the poverty line. Households with handicapped persons made up $4.8 \%$ of all households in 1993, with $39.3 \%$ of all households with handicapped persons below the poverty line. In $1992,40.2 \%$ of handicapped households were below the poverty line, so there was a slight improvement in their incidence of poverty. In 1993, $47.2 \%$ of households with an unemployed person were below the poverty line, which is down from nearly $50 \%$ in 1992 . But note that the proportion of all households with unemployed persons rose from $7.8 \%$ in 1992 to almost $10 \%$ in 1993 .

The one group that appears to have fared relatively well is households with retirement-age persons. From the last row in table $6 \mathrm{~A}$ we see that fewer than $17 \%$ of these households fall below the poverty line, and this fraction is down from $24.4 \%$ in 1992 . Pensioners as a group have not shared equally in the burdens of economic reform, and they are the only group that appears actually to have seen significant improvements in their disposable incomes during the first 2 years of the reforms.

We next examine whether there is evidence of significant longer- 
term economic hardship. Table 7 presents a household-level transition matrix for movements among income categories from 1992 to $1993 .^{25}$ During these 2 years there were significant movements of households within the income distribution. In $1992,54.6 \%$ of those in poverty had above-poverty incomes in 1993, and only about one-quarter of the very poor in 1992 remained very poor in 1993. In 1993, 54.1\% of those in poverty had been above the poverty line in 1992. While there is evidence of some persistence in poverty, these figures suggest that poverty status was only a temporary state for the majority of households during this period.

Table 8 presents summary labor force statistics for working-age men (age 18-59) and women (age 18-54) in 1992 and 1993. Sizable dislocations did take place in the labor market during this year. The unemployment rate rose by nearly one-third, from $5.6 \%$ of the labor force to $7.2 \%$. In addition, there was a large movement of individuals out of the labor force, with the labor force participation rate dropping from $87.2 \%$ to $82.9 \%$ during this year.

A more important issue is whether these changes in labor force status indicate a significant amount of long-term labor market dislocations. Table 9 presents the transition matrix for movements from labor force status categories in 1992 to 1993 labor force categories. ${ }^{26}$ This table includes only those working-age adults who were interviewed in both 1992 and 1993. The row labels indicate the labor force status at the interview in 1992, and the column headings indicate the labor force status at the interview in 1993. The far right column describes the

TABLE 7

Household Transitions among Income Categories, 1992-93

\begin{tabular}{|c|c|c|c|c|}
\hline \multirow{2}{*}{$\begin{array}{l}1992 \text { InCOME as \% } \\
\text { OF THE Poverty Line }\end{array}$} & \multicolumn{3}{|c|}{$\begin{array}{l}1993 \text { Income as a Percentage } \\
\text { OF THE Poverty Line }\end{array}$} & \multirow{2}{*}{$\begin{array}{c}\text { TOTAL \% IN } \\
\text { INCOME CATEGORY, } \\
1992\end{array}$} \\
\hline & $<50 \%$ & $51 \%-100 \%$ & $>101 \%$ & \\
\hline$<50 \%$ & $\begin{array}{l}28.5 \\
(89)\end{array}$ & $\begin{array}{l}33.0 \\
(103)\end{array}$ & $\begin{array}{l}38.5 \\
(120)\end{array}$ & $\begin{array}{l}6.3 \\
(312)\end{array}$ \\
\hline $51 \%-100 \%$ & $\begin{array}{l}13.4 \\
(144)\end{array}$ & $\begin{array}{l}27.3 \\
(293)\end{array}$ & $\begin{array}{l}59.3 \\
(637)\end{array}$ & $\begin{array}{l}21.6 \\
(1,074)\end{array}$ \\
\hline$>101 \%$ & $\begin{array}{l}5.6 \\
(202)\end{array}$ & $\begin{array}{l}15.1 \\
(540)\end{array}$ & $\begin{array}{c}79.3 \\
(2,845)\end{array}$ & $\begin{array}{l}72.1 \\
(3,587)\end{array}$ \\
\hline $\begin{array}{l}\text { Total \% in income category, } \\
1993\end{array}$ & $\begin{array}{l}8.7 \\
(435)\end{array}$ & $\begin{array}{l}18.8 \\
(936)\end{array}$ & $\begin{array}{c}72.4 \\
(3,602)\end{array}$ & $\begin{array}{l}100.0 \\
(4,973)\end{array}$ \\
\hline
\end{tabular}

SourCE.-Russian Longitudinal Monitoring Survey, July-October 1992 and JulySeptember 1993.

NoTE.-\% of households from each 1992 income category moving to each 1993 income category. The numbers in parentheses are the counts of the number of households in each cell. Sums may not total to 100.0 because of rounding. 


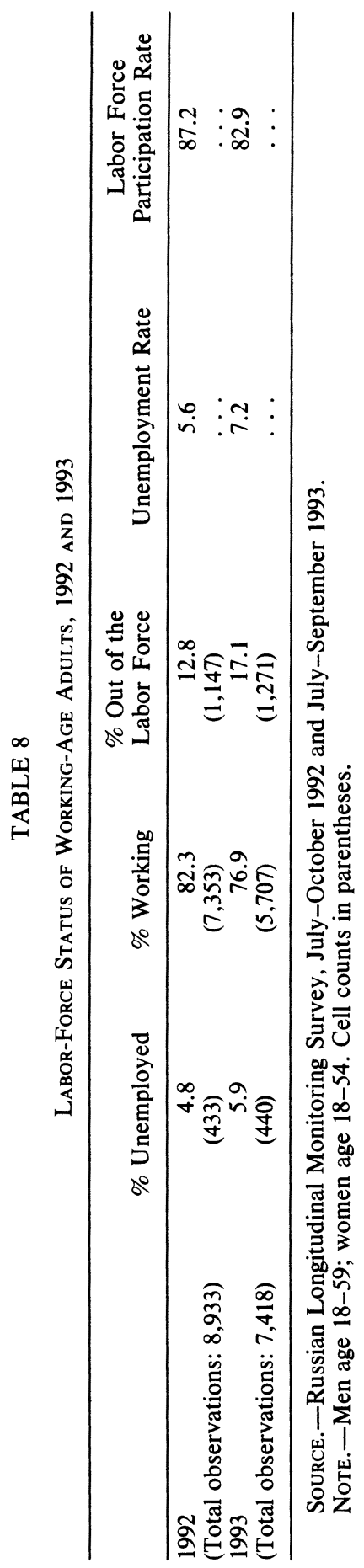


TABLE 9

Transitions among Labor-Force Categories, 1992-93

\begin{tabular}{lcccc}
\hline & \multicolumn{3}{c}{1993} & \\
\cline { 2 - 4 } 1992 & Unemployed & Working & $\begin{array}{c}\text { Out of the } \\
\text { Labor Force }\end{array}$ & $\begin{array}{c}\text { OvERALL } \\
1992 \\
\text { Distribution }\end{array}$ \\
\hline Unemployed & 20.3 & 49.2 & 30.5 & 4.4 \\
Working & $(62)$ & $(150)$ & $(93)$ & $(305)$ \\
Out of the labor force & 4.6 & 86.8 & 8.5 & 83.7 \\
Overall 1993 distribution & $(266)$ & $(4,983)$ & $(489)$ & $(5,738)$ \\
& $(6.1$ & 21.6 & 70.2 & 11.9 \\
& 5.7 & $(176)$ & $(571)$ & $(813)$ \\
& $(394)$ & $(5,309)$ & $(1,153)$ & $(6,856)$ \\
\hline
\end{tabular}

SourcE.-Russian Longitudinal Monitoring Survey, July-October 1992 and JulySeptember 1993.

NoTE.-\% of individuals in 1992 employment category moving into each 1993 employment category. Working-age adults: men 18-59; women 18-54. Cell counts in parentheses.

distribution of labor force status in 1992 for this subsample, and the bottom row presents the distribution of labor force status in 1993. The other entries in the table indicate, for each 1992 labor force status, the percent of individuals who were in each of the three labor force statuses in 1993. Of those working in 1992, for example, $8.5 \%$ were not in the labor force in 1993.

This table reveals that about half of those unemployed as of the 1992 interview had found jobs by the 1993 interview, and only about one-fifth of those unemployed in 1992 were also unemployed at the time of the 1993 interview. However, 30\% of the unemployed in 1992 were not in the labor force as of 1993 . Less than $5 \%$ of the workers in 1992 were unemployed as of 1993 , and over $20 \%$ of those out of the labor force in 1992 had jobs in 1993.

The picture portrayed in table 9 indicates significant entry into the labor force by the unemployed and those out of the labor force. It also indicates that only a small minority of 1992 workers could have been experiencing a long-term spell of unemployment. There is, however, some indication that a sizable fraction of the unemployed might be experiencing lengthy spells without jobs, and the decline in the labor force participation rate of the prime-age workers may be indicating the start of serious labor force dislocations.

The final question concerning the recent experiences in Russia is whether there were hunger, malnutrition, or other serious signs of significant problems. The answer is, in general, no; but there are indications that infants' nutritional status did deteriorate between 1992 and 1993. Table 10 presents some summary statistics on children's 


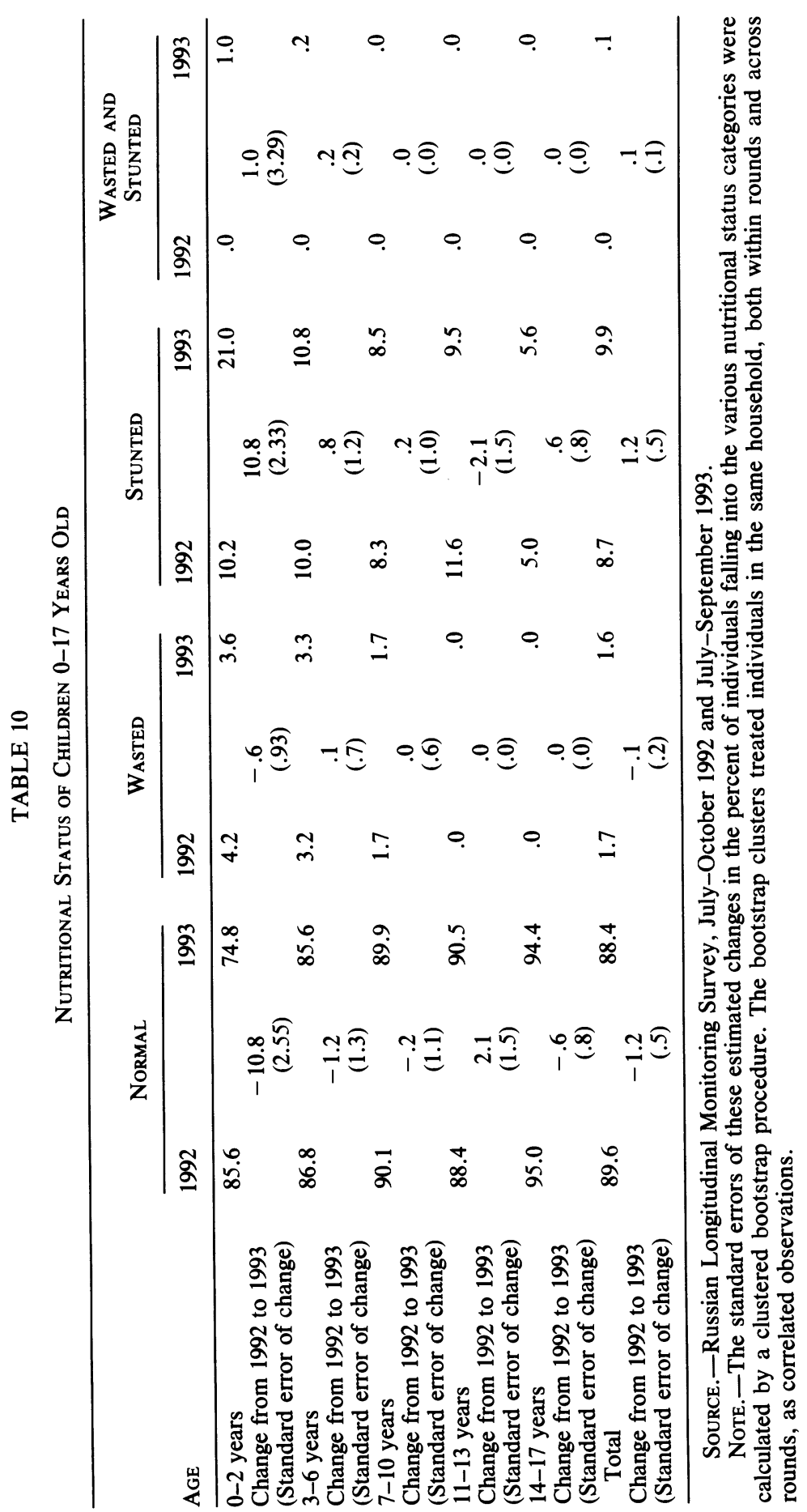


nutritional status, and table 11 describes adults' nutritional status. In 1992 there did not appear to be any indications of significant problems. The major change between 1992 and 1993, as shown in tables 10 and 11 , concerns the well-being of children. Infants 0-2 years old experienced more than a doubling in the instance of stunting (height more than two standard deviations below the WHO height for age standard) from 1992 to 1993 . This increase is statistically quite significant. This result coincides with the above description of the increase in the fraction of children in poverty. The proportion of children who are wasted (more than two standard deviations below the WHO weight for height standard) is similar to what we would find in Latin America.

Particularly in 1993, the proportion of stunting is higher than would be expected, and the large increase in stunting among children up to age 2 indicates problems in the feeding of young children. Without detailed analysis of this problem we can only speculate that the elimination of government programs might be partly responsible for this change. In particular, the government eliminated programs that provided free infant formula and other nutrient-dense foods to infants, and there were significant cutbacks in the funding provided to kindergartens (the name for enterprise- or government-funded preschool programs) during this transition.

There are several less dramatic but notable changes evident in table 11. There is a small increase in underweight status for young adults, and the incidence of being overweight or obese increased slightly for middle-aged adults and the elderly. Both the increase in underweight status for young adults and the increase in obesity for the elderly are statistically significant, and these changes in nutrition status accord with the changes in the incidence of poverty for these two groups.

\section{Discussion}

During the period prior to the remarkable breakup of the Soviet Union and the creation of the Russian Federation into an independent country, a complex system of social protection developed. Political demands during the first 30 years of the Soviet Union, combined with minimal or no hunger during the 1950-90 period, did not force the government to consider alternate ways of measuring the welfare of the country, and there was no need to question or change the existing statistical system. The household survey system used in the Soviet Union was unequipped to ascertain who were truly in need of social protection by the state, whether there was significant unemployment, or who the poor actually were. The existing paradigm of poverty and all transfers focused on those identified as being poor or most vulnerable under the old system. ${ }^{27}$

The RLMS reflects a major change in the survey system of Russia, 


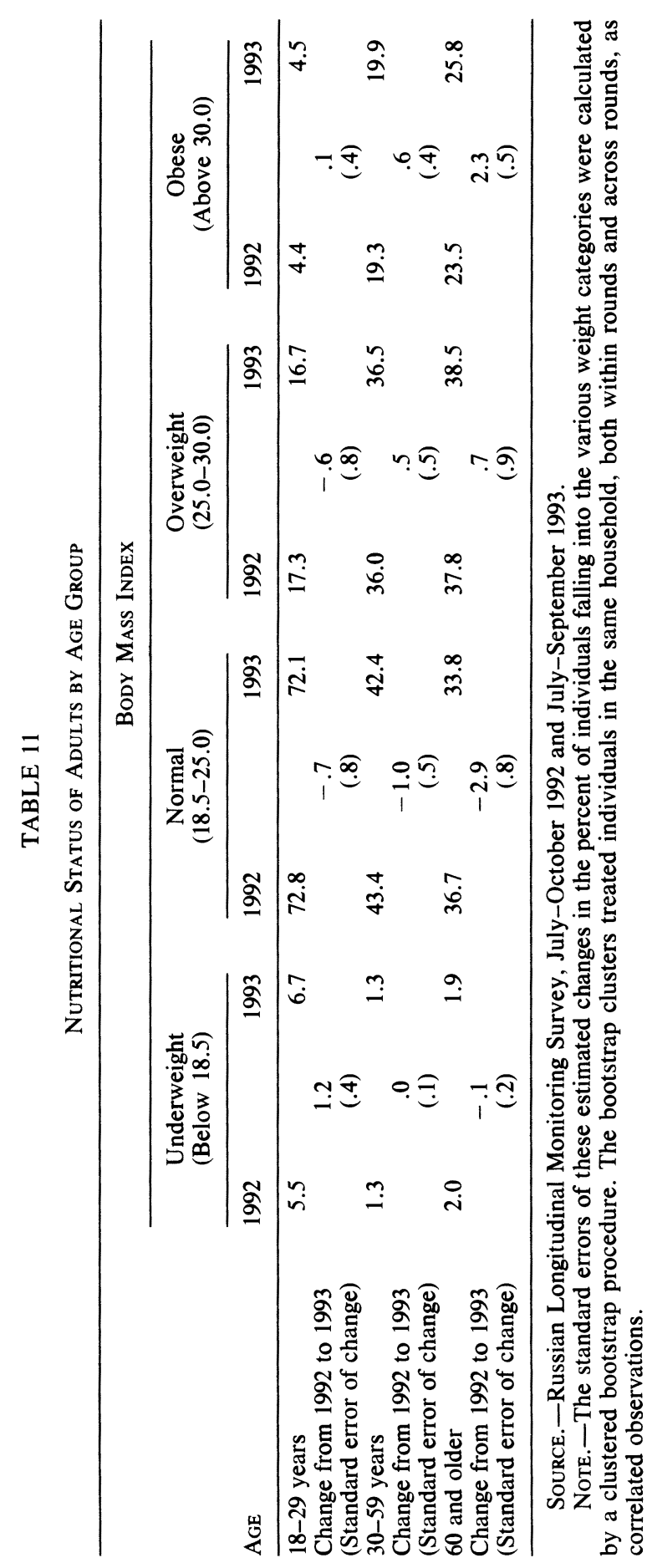


and it will help to develop a clearer allocation of resources to help the poor. It portrays a significantly different profile of poverty than the Goskomstat surveys. Part of the difference between the RLMS results and those of the Consumer Budget Survey might be ascribed to economic reforms. However, since the patterns and levels of poverty in the Taganrog survey collected in 1989 and those in the 1992 round 1 of the RLMS are similar, we suspect that the reforms have not yet significantly changed the dimensions of poverty. On this point we differ from many analysts who have focused most of their analysis on the Goskomstat surveys and have viewed the transition to the market economy as having exacerbated the problem of poverty even during the first year of the transition. ${ }^{28}$ These same researchers state that unemployment has increased considerably during this period, but we do not find evidence for exceptionally high levels of unemployment. Of equal importance, the RLMS results will provide guidance regarding the components of the current transfer system that must remain in place if particular sociodemographic groups are to be kept out of poverty.

A most crucial question is, Where is the social safety net? The social protection system of providing hundreds of different transfers to persons of retirement age, children in large families, single-parent households, and the handicapped, was believed to have covered the poor during the period before 1992. As shown in our discussion of Goskomstat's Consumer Budget Survey and the Taganrog survey, this may not actually have been the case. The results of rounds 1 and 3 of the RLMS show that many groups, particularly children, the unemployed, and the working poor, did not receive adequate transfers in 1992 and 1993. Moreover, the anthropometric results on child nutritional status, presented in table 10 , point out an emerging problem facing young children.

Table 12 presents the proportion of income received from transfer payments categorized by income as a proportion of the poverty line. Those under the direst of circumstances of poverty received less than half of their income from transfers. For instance, households with unemployed persons and with incomes below the poverty line received about one-quarter of their total income from public transfers in 1993; it was more than $30 \%$ in 1992 . While these amounts of support are significant, they are inadequate to keep households that experience unemployment out of poverty. The working poor received considerably less than $20 \%$ of their total income from public transfers. In contrast, poor pensioners received almost two-thirds of their income from public transfers in both 1992 and 1993.

Households with retirement-age persons fared much better than most other households during 1993. The main reason is that pensions kept up with the rapid inflation. To examine this issue in more detail, 


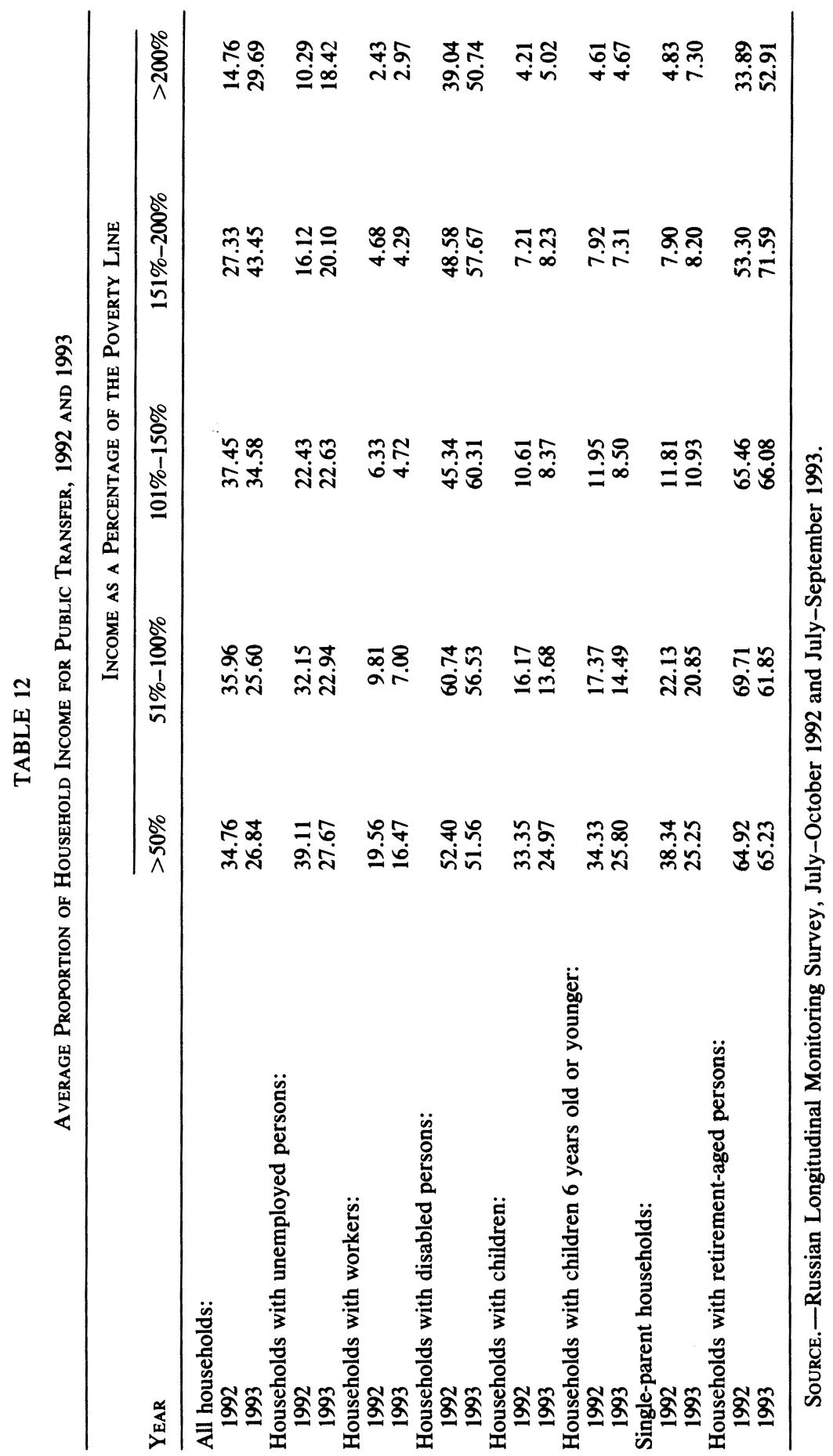


we hypothetically removed one-half of the pension income from those households, and recalculated the proportion of households with elderly persons that fell below the poverty line. Given the high rate of inflation, this hypothetical pension reduction is similar to a 2-3-month delay in readjusting the pension benefits. After this hypothetical reduction in pensions, the fraction of households with elderly in poverty rises from $17 \%$ to $44 \%$ in 1993; almost half of all poverty households would have retirement-age persons. In an additional experiment, we hypothetically removed all pension income. In this instance, nearly $70 \%$ of the households with elderly individuals fell below the poverty line, with over half of the households with elderly persons showing incomes less than one-half the poverty line. The social protection programs are clearly a major reason why so few elderly are in poverty.

Overall, we find little evidence of rapidly increasing economic hardship from 1992 to 1993 in Russia. In part, this appears due to how Russian households adapted to the changing economic and social conditions. There were significant increases in home production since the institution of the economic reforms. Households also appeared to be selling assets to offset reductions in labor incomes. In addition, the composition of diets shifted slightly away from protein consumption. ${ }^{29}$ These three changes do indicate that Russian households felt pressured by the economic reforms, but they also suggest why there are so few indications of increasing poverty.

More careful analyses of true poverty and its welfare implications are needed. This is particularly true for children, as our results indicate an increase in poverty and undernutrition among children. There should be less reliance on public opinion, the concept of social minimum income, and many unsubstantiated statistics. ${ }^{30}$ Some means testing or other approaches will be needed to ascertain that working poor need assistance; and the problems of the unemployed will need to be studied and addressed. It will be necessary to develop and implement social programs that provide assistance and incentives for people to adapt to the changing structure of the society and the economy. More detailed analyses of the nature of poverty and the role of transfer programs are needed. Additional analyses of the dynamics of poverty during the first 2 years of the transition will be crucial, and such studies may point out additional ways to develop an effective and meaningful social safety net. 


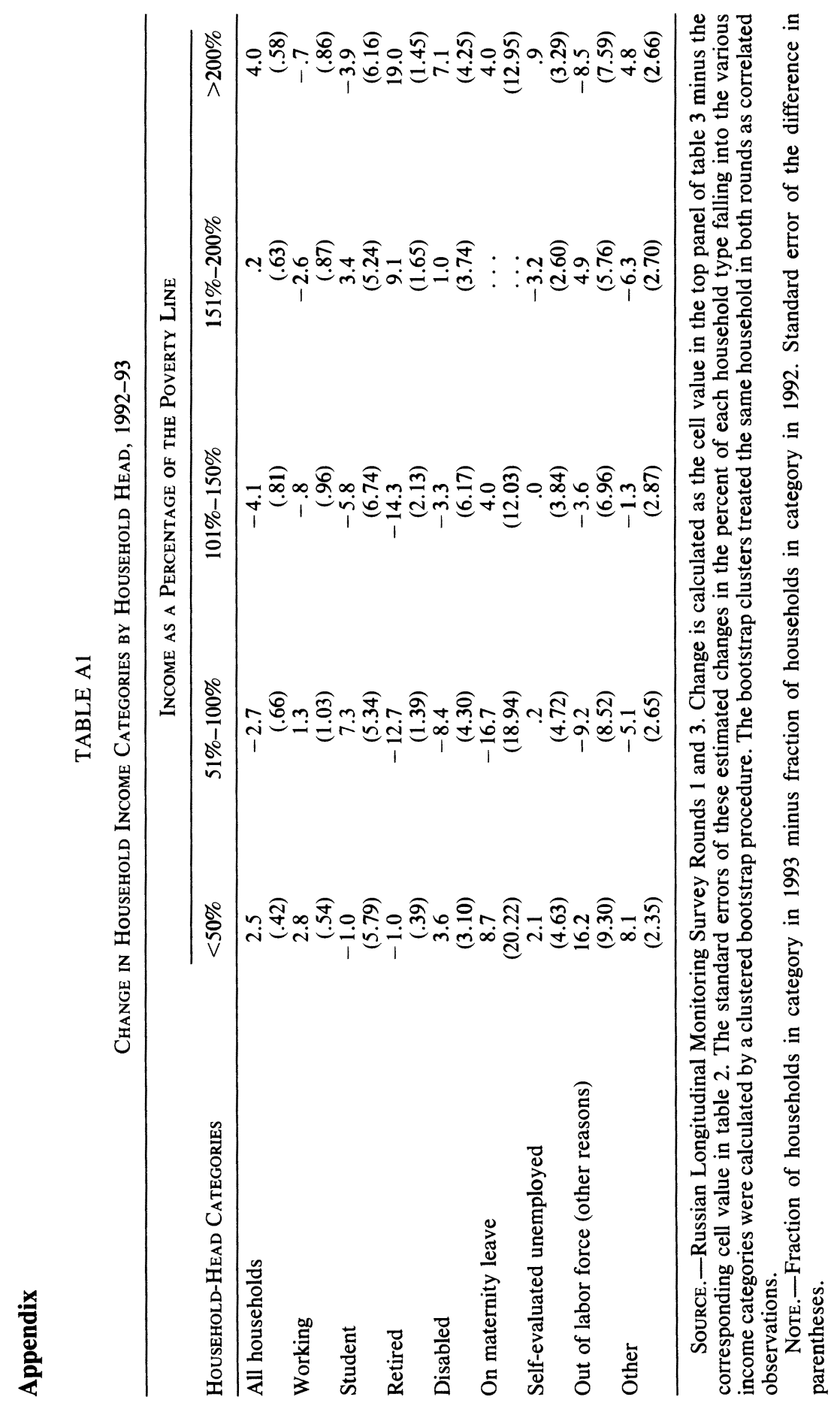




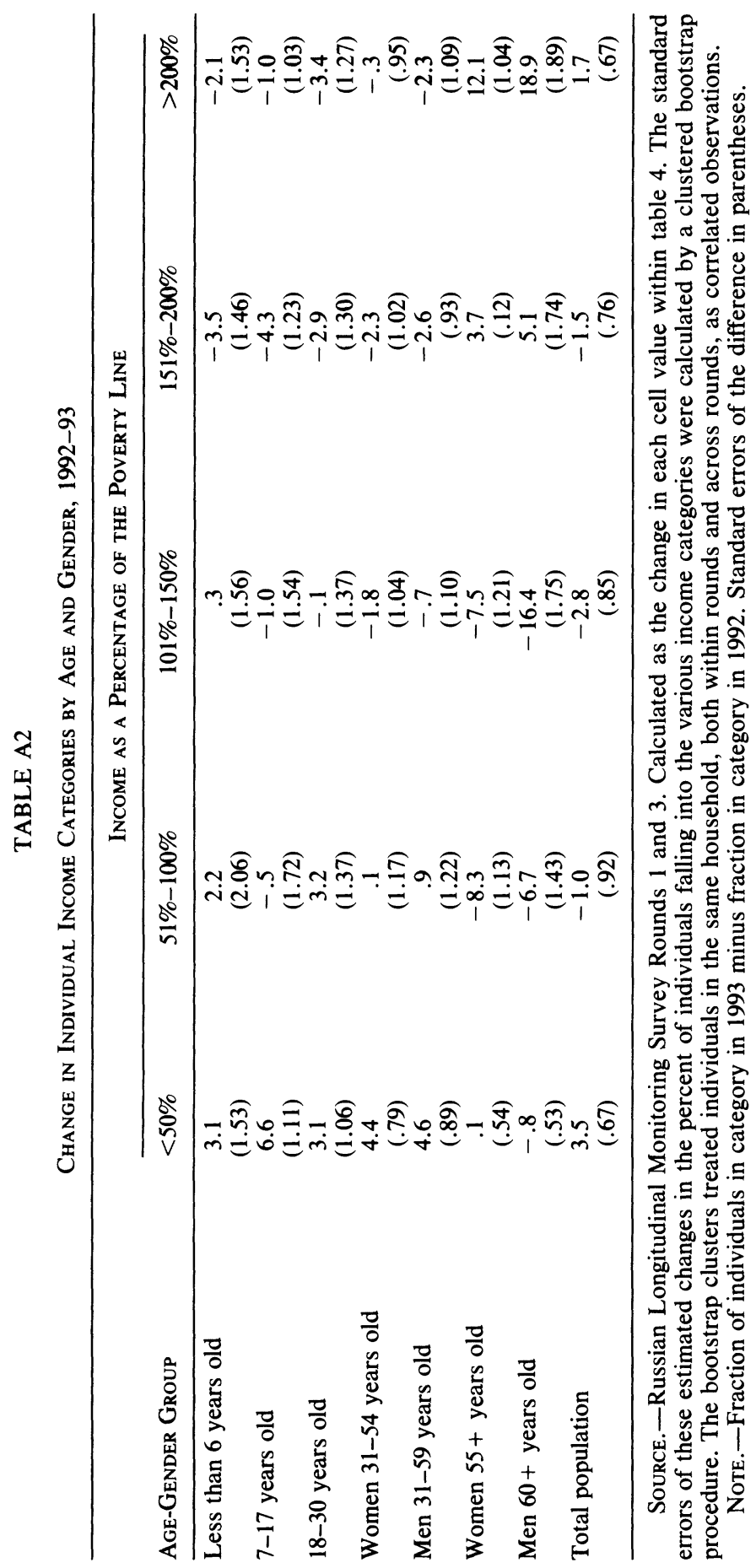




\section{Notes}

* Some of the initial work was funded by the World Bank from 1991 to 1992. Subsequent work received the support of the Carolina Population Center, the U.S. Agency for International Development, and the National Institutes of Health (RO1HD30880). At the time of the first three rounds, the Russian Longitudinal Monitoring Survey was a collaborative project of the University of North Carolina at Chapel Hill, the Goskomstat, the Russian Center of Preventive Medicine (RCPM), and the Russian Institute of Sociology (ISRosAN). Key collaborators with us in this survey are Barbara Entwisle, Lenore Kohlmeier, Michael Swafford, and Namvar Zohoori, United States; Alexander Nikolarvitch Ivanov and Igor Ivanovitch Dmitrichev, Goskomstat; Polina Kozyreva and Michael S. Kosolapov, ISRosAN; and Svetlana Shalnova and Alexander Deev, RCPM. A number of persons have provided important assistance in this work on poverty in Russia, including Harold Alderman, Robert Liebenthal, and especially Timothy King. We thank Igor Ivanovitch Dmitrichev, Russian Goskomstat, and Marina Mozhina, Institute for SocioEconomic Population Studies, for their assistance in providing background data used in this article. Elena Glinskaya, Andrey Lukashov, Michael Lokshin, Karin Gleiter, Laura Klein, and David Robinson provided help with the RLMS and Frances Dancy assisted with support in administrative matters. We thank them all. 174-76.

1. Mervyn Matthews, "Poverty in Russia," New Society 19 (1972):

2. Ibid.

3. Behind this Russian market basket are a set of nutritional guidelines. These guidelines were promulgated during the 1950 s by the Institute of Nutrition, Soviet Academy of Medical Sciences, as part of an effort of the former Soviet Union to compete with the West. A primary concern was with achieving levels of production and consumption comparable with the West, particularly in the meat and dairy sectors (Alexander Baturin, Deputy Director, Russian Institute of Nutrition, personal communication, December 1993). Nutritionists set a rational standard of annual consumption of 84 kilograms per capita of meat, and this was used to develop national production goals. No nutritional standard was mentioned in speeches, but if one divided the national production levels noted in speeches of Brezhnev or Khrushchev by total population, 84 kilograms per capita per year was the result. (For more detail, see Barry Popkin, Lenore Kohlmeier, Namvar Zohoori, Alexander Baturin, Arseni Martinchik, and Alexander Deev, "Nutritional Risk Factors in the Former Soviet Union," in Adult Health in the Former Soviet Union [Washington, D.C.: National Academy of Sciences, in press].) This diet represented a level of dietary intake considerably higher than what the World Health OrganizationFood and Agriculture Organization (WHO-FAO) and other nutrition and health bodies recommend to enable a person to be healthy and active.

4. There were extensive reports in the international press that $85 \%-88 \%$ of all Russians were poor. These estimates were based on this social minimum income.

5. Barry M. Popkin, M. Mozhina, and A. K. Baturin, "The Development of a Subsistence Income Level in the Russian Federation" (University of North Carolina at Chapel Hill, 1992, unpublished manuscript).

6. Molly Orshansky, "Counting the Poor: Another Look at the Poverty Profile," Social Security Bulletin (January 1965), pp. 3-26.

7. With National Institute of Aging and Bureau of Census funding, these same Russian researchers are reinterviewing the Taganrog households in 1994-95. 
8. Natalia Rimashevskaya, "Taganrog Studies: Family Well-Being, Conditions, Standards, Way and Quality of Life of the Population of Russia", (our translation of paper presented at the University of North Carolina at Chapel Hill and Duke University, June 1992). We will be pleased to provide either this translated paper by Rimashevskaya or references to the numerous Russian language books written on the Taganrog studies.

9. It is important to note that the cluster design approach used here requires that we adjust the information presented for these design effects. The necessary sampling research to do this is not yet completed, so we present unweighted results.

10. Popkin et al., "The Development of a Subsistence Income Level in the Russian Federation.',

11. Note that the new poverty line does not incorporate detailed adjustments for economies of scale associated with family size or regional price variations.

12. The results reported here come from tabulations prepared by Marina Mozhina. More detailed information on the incidence of poverty from the 1989 and 1991 Consumer Budget Surveys and the Taganrog survey are available on request from us. There are significant data constraints in using the Consumer Budget Surveys. There are no computer tapes of the raw data, and the government is forced to use only computerized summary tables.

13. Rimashevskaya.

14. Alexander Samorodov, "Transition, Poverty and Inequality in Russia," International Labor Review 131 (1992): 335-53.

15. L. Zubova, N. Kovaleva, and L. Khakhulina, "Poverty in the USSR," Problems of Economics 34 (1992): 85-98.

16. Centers for Disease Control, "Public Health Assessment-Russian Federation," Morbidity and Mortality Weekly Report 41 (1992): 809-11; Matthews (n. 1 above); Jeanine Braithewaite, "Income Distribution and Poverty in the Soviet Republics," Journal of Soviet Nationalities 1 (1990): 158-73; Samorodov.

17. Ward Kingkade and Barbara Torrey, "The Evolving Demography of Aging in the United States of America and the former USSR," World Health Statistics Quarterly 45 (1992): 15-28.

18. Sandor Sipos, "Poverty Measurement in Central and Eastern Europe before the Transition to the Market Economy," Innocenti Occasional Papers Economic Policy Series, no. 29 (Unicef Innocenti Center, Florence, 1992); Samorodov.

19. These same patterns are found across republics, particularly between the central Asian republics and the other republics. In this case, higher fertility rates in these predominantly Moslem republics appear to be combined with lower wage structures to produce the differential distribution of absolute poverty levels.

20. In all tables using income measures in this study we exclude households that had more than 250 rubles per capita (June 1992 rubles) in investments for farming or business during the month preceding the survey. This restriction arises because we use a disposable income measure when defining poverty. Without this restriction many of these investor households would appear to be quite poor, and our analysis of these households shows us that they are probably relatively wealthy households. This restriction drops 56 households in round 1 and 47 households in round 3, or fewer than $1 \%$ of the households in each round. The basic poverty tabulations are quite insensitive to these exclusion criteria.

21. Our definition of the household head is arbitrary. We used the follow- 
ing sequential criteria to select the "head": (1) the oldest working-age male (age 18-59), (2) the oldest working-age female (age 18-54), (3) the youngest retirement-age male (age $60+$ ), (4) the youngest retirement-age female (age $55+$ ), and (5) the oldest other person in the household.

22. Recall that the household poverty lines reflect the age and gender composition of each household and use monthly national food prices to update the cost of each item in each demographic group's food basket.

23. Appendix table A1 only compares the changes, from 1992 to 1993, in the estimates reported in the top parts of tables 2 and 3.

24 . Recall that these poverty lines do incorporate different nutritional requirements for individuals in different demographic categories. In this sense, the poverty lines we use do adjust for "equivalence scales." They do not, however, adjust for "economies of scale" that may be due to larger households being able to produce twice as much for less than twice the expenditure.

25 . For a household to be included in this table, it must have been interviewed in both the round 1 and round 3 surveys and must have had no severe data problems in each survey. About $15 \%$ of the households surveyed in round 1 were not included in table 7 for these reasons. This $15 \%$ loss to follow-up between rounds 1 and 3 is similar to that experienced in the first three waves of the Panel Study of Income Dynamics (Sean Becketti, William Gould, Lee Lillard, and Finis Welch, "The Panel Study of Income Dynamics after Fourteen Years: An Evaluation," Journal of Labor Economics 6, no. 4 [1988]: 472-92). Four percent of the households actually interviewed in round 3 were deleted from table 7 because they had not been interviewed in round 1 . Note that the marginal distributions in both 1992 and 1993 for this continuously observed sample match closely those of the entire sample in both years.

26. Sample attrition was fairly high, and this may cause some biases in the transition estimates. The marginal distributions based on the subsample of persons observed both in 1992 and 1993 (in the last row and last column of table 9), however, are quite close to the marginal distributions of labor force status for all individuals interviewed during each round of the survey (cols. 1-3 in table 8).

27. Samorodov (n. 14 above).

28. Ibid.; Braithewaite (n. 16 above).

29. Popkin et al., "Nutritional Risk Factors in the Former Soviet Union" (n. 3 above).

30. Samorodov. 